\title{
Postmortem biyokimya
}

\section{Postmortem biochemistry}

\section{Mukaddes Gürler ${ }^{1,2}$, Aynur Altuntaş ${ }^{3}$}

\section{ÖZET}

Postmortem biyokimya son yıllarda hızla adli patoloji alanında rutin kullanıma girmeye ve bu alanda giderek önem kazanmaya başlamıştır. Rutin uygulanan ful otopsi içinde biyokimyasal incelemelerin de yer alması; ölüm öncesi var olan akut/kronik patolojileri, ölüme sebep olabilecek hastalıkları, ölüm sürecinde kişinin metabolik durumunu, canlılık süresini, ölüm sonrası biyokimyasal değişiklikleri ve analitlerin kaynağını göstermesi açısından önemli bilgiler sağlayabilir. Özellikle klasik otopsi ile yapılan morfolojik incelemelerin yetersiz kaldığı durumlarda (Diabetes Mellitus (DM), alkolik ketoasidoz, sepsis, elektrolit bozuklukları) biyokimyasal tetkikler çok değerli olabilir. Bu yazıda literatür araştırmasına dayalı postmortem biyokimya ile ilgili yapılmış çalışmalara atıfta bulunarak otopsi incelemelerinde başvurulabilecek biyokimyasal analitler üzerinde kısaca durulmuştur.

Anahtar kelimeler: Postmortem biyokimya, postmortem kimya, adli kimya

\section{GíRiş}

Son 15 yıldır üzerinde daha sıklıkla durulan "Postmortem Biyokimya" ile ilgili ilk çalışmalar 1993'de yapılmışıtır [1]. Coe, Adli Kimya'yı “Adli patologlar için önemli kadim işlemlerden biri" şeklinde nitelendirmiş ve göz içi sıvısında (GISS) sadece glukoz, elektrolit ve üre azotu tayin edilerek vakaların $\% 5$ inden fazlasında ölüm zamanının belirlenebileceğini, daha da önemlisi adli soruşturmaların çözümünde $\% 10$ katkı sağlayabileceğini vurgulamıştır.

Coe'dan sonra da birçok araştırmacı bu konuya farklı açılardan yaklaşarak doğru örnekleme,

\begin{abstract}
Postmortem biochemistry is becoming more important in forensic pathology. Involving of biochemical investigations full autopsy can provide to detect divers pathologic conditions such as antemortem acute/chronic diseases, fatal metabolic conditions, survival time, postmortem biochemical changes, and the source of analytes. Biochemical tests may be usefull where the morphological examinations cannot lighten the fatal pathology (Diabetes Mellitus (DM), alcoholic ketoacidosis, sepsis, electrolytic disorders). This article presents the analytes that may be useful in forensic medicine upon the studies performed and published in the literature.
\end{abstract}

Key words: Postmortem biochemistry, postmortem chemistry, forensic chemistry

uygun analiz tekniğinin seçimi ve ölçüm doğruluğu gibi konularda çalışmalar yapmışlardır. Böylece günümüze kadar birçok biyolojik örnekte çok çeşitli maddelerin uygun teknik altyap1 ile postmortem tespiti yapılabilir hale gelmiştir.

Postmortem biyokimyasal belirteçleri aşağıdaki ana başlıklar altında ele alabiliriz:

1. Karbonhidrat metabolizmas1 ile ilgili belirteçler

2. Böbrek fonksiyonu ile ilgili belirteçler

3. Karaciğer fonksiyonu ile ilgili belirteçler

4. Kalp fonksiyonu ile ilgili belirteçler

\footnotetext{
${ }^{1}$ Hacettepe Üniversitesi, Tıp Fakültesi, Tibbi Biyokimya ve Adli Tıp AD, Ankara, Türkiye ${ }^{2}$ Ankara Üniversitesi Adli Bilimler Enstitüsü, Adli Toksikoloji AD, Ankara, Türkiye

${ }^{3}$ Adli Tıp Kurumu Ankara Grup Başkanlı̆̆̆, Kimya İhtisas Dairesi, Ankara, Türkiye
}

Yazışma Adresi /Correspondence: Mukaddes Gürler, Hacettepe Üniversitesi Tıp Fakültesi Tıbbi Biyokimya ve Adli Tıp AD, Ankara, Türkiye Email: dr.mkdds@gmail.com 

leri

5. Sepsis, enflamasyon ve enfeksiyon belirteç-

6. Anaflaksi ile ilgili belirteçler

7. Hormonlar

8. Diğer testler

\section{KARBONHIDRAT METABOLIZMASI İLE İLGILII BELİRTEÇLER}

Glukoz (GİS / Beyin-Omurilik Sıvıs1, BOS) s

Glikolize hemoglobin (kan)

Laktat (kan, GIS)

Keton cisimleri (kan / GİS)

İzopropil alkol (IPA) (biyolojik sıvılarda)

İnsülin ve $C$ peptid

Göziçi sıvısı ya da beyin omurilik sıvısı (BOS) glukozunun $20 \mathrm{mmol} / \mathrm{L}(360 \mathrm{mg} / \mathrm{dL})$ ve üzeri, laktatın $23,4 \mathrm{mmol} / \mathrm{L}(422 \mathrm{mg} / \mathrm{dL})$ den yüksek, 3HB (3-hidroksibütirat)'ın $\quad 1000 \mu \mathrm{mol} / \mathrm{L} \quad(10,4 \mathrm{mg} / \mathrm{dL})$ üzerinde olması yanında yükselmiş glikozile $\mathrm{Hb}$, aseton ve 3HB değerleri DM veya DKA (Diabetik Ketoasidoz) lehinedir [2-5]. Ketozise bağlı artmış olan aseton yüksek NADH varlığında IPA'e dönüşür. Hipotermi ve ani alkolik ölümlerde de IPA yararlı bir belirteçtir [6].

Kanda yüksek keton cisimleri bulunan vakalar "ketoalkolik ölüm" olarak tanımlanır [7]. Kanda $10,000 \mu \mathrm{mol} / \mathrm{L}$ ve GIS'da $5,000 \mu \mathrm{mol} / \mathrm{L}$ üzerinde bulunan keton cisimleri seviyesi alkolik ketoasidoz için anlamlıdır [8].

Alkolik laktik asidoz için bazı kriterler belirlenmiştir. Bunlar; glukoz ve laktatın toplam düzeyinin $300 \mathrm{mg} / \mathrm{dL}$ (16.6 mmol/L) ve üzerinde olması, hikayesinde diyabetin bulunmaması ve ağır zehirlenme de dahil bilinen başka ölüm sebebinin olmamasıdır.

İnsülinle birlikte $\mathrm{C}$ peptid ölçümü hipoglisemi teşhisi açısından önemlidir. I/C $>1$ ise eksojen insülin, $\mathrm{I} / \mathrm{C}<1$ ise insulinoma veya sulfonilure aşırı dozu söz konusudur. Analiz için periferal kan örneği daha uygundur çünkü kalp kanı yüksek değerler gösterir. Perikard sıvısının da uygun bir örnek olabileceği belirtilmiştir [5]. Ayrıca enjeksiyon bölgesinden alınan doku örneğinde insülin varlığını göstermek de önemli bir bulgudur. Postmortem serum insülin değerlerinin letal dozunu belirlemek zordur. Bir çalışmada normal açlık (5-75 $\mu \mathrm{UI} / \mathrm{ml}-35-521 \mathrm{pmol} / \mathrm{l})$ ve fatal insülin ((800-3,200 $\mu \mathrm{IU} / \mathrm{ml}-556-22,224$ pmol/l) değerleri rapor edilmiştir [9]. Başka bir araştırmaya göre en düşük letal insülin düzeyi 100 $\mu \mathrm{IU} / \mathrm{ml} \operatorname{dir}[10]$.

\section{BÖBREK FONKSIYYONU ILE İLGILİ BELİRTEÇLER}

Üre azotu (serum ve biyolojik sıvılar)

Kreatinin (serum, idrar)

Ürik asit (serum, perikard sıvisı)

Elektrolitler ( $\mathrm{Na}, \mathrm{K}, \mathrm{Cl}, \mathrm{Ca}, \mathrm{Mg}, \mathrm{Sr}$ )

Dehidratasyon vakalarında yüksek postmortem serum ve GİS üre azotu, yüksek GíS $\mathrm{Na}$ ve $\mathrm{Cl}$ ve normal serum ve GISS kreatinin değerleri elde edilir. Ürik asidin postmortem serumda özellikle de sağ kalp kanında artışı mekanik asfiksi ve boğulmayı gösterir. Agonal konvülsiyon veya hiperaktiviteye bağlı hipoksik iskelet kası hasarında da hiperürisemi görülür.

Ağır ölümcül hipertermili vakalarda kreati$\operatorname{nin}(2 \mathrm{mg} / \mathrm{dL}$ üzeri) değerleri yüksek bulunur [11] DKA'da postmortem serum ve GIS'da üre azotu yüksek, kreatinin ise normaldir [5]. Üre azotu için bir farkl1l1k gözlenmezken, kreatinin için en iyi örnek sol kalp kanıdır [12]

Postmortem ATP'nin olmaması hücre zarı geçirgenliğini artırır. Hücre içi ve dışı arasındaki elektrolit ve sıv1 dengesi bozulur, hücrede otoliz meydana gelir.

Hipernatremide GİS Na değeri 155 - 210 $\mathrm{mmol} / \mathrm{L}$, GİS Cl değeri 139-147 mmol/L düzeylerindedir [1,13-15]. Postmortem $120 \mathrm{mmol} / \mathrm{L} \mathrm{Na}$ değeri hiponatremiyi işaret eder (16).

Anlamlı olmayan yüksek $\mathrm{K}$ değerine nazaran düşük GISS K değeri teorik olarak hipokalemi lehinedir [1]. Kalp kanı ve periferik kan örneklerinde özellikle de sağ kalp kanı serumunda $\mathrm{Ca}$ ve $\mathrm{Mg}$ değerleri tuzlu suda boğulmalarda anlamlı ölçüde yüksektir $[17,18]$.

Hipotermide perikardial $\mathrm{Ca}$, tatlı su boğulmalar1 ve yanginlarda ise serum Ca'u artar [17].

Tuzlu suda boğulmalarda sol ve sağ kalp Sr oranının $75 \mu \mathrm{g} / \mathrm{L}$ den fazla olması anlamlıdır. Özellikle 72 saatten az sürede suda kalmış cesetlerde kalp kanında Sr bakılması teşhiste daha yararlıdır [19-25]. 


\section{KARACIĞER FONKSIYONU İLE İLGILİ BELİRTEÇLER}

Kolesterol (sağ kalp kan1), Bilirubin (femoral ven kan1) ve Protein

\section{Alkol bağımlığı ve alkol alımı ile ilgili belirteçler: Karbonhidrat eksik transferrin (Carbohydrate- deficient transferrin, CDT), Etil glukuronid (EtG) ve Etil sülfat (EtS)}

CDT terminal oligosakkarit eksikliği gösteren transferrin (Tf) izoformlarıdır (asialo/disialo Tf). 1-2 hafta süreyle, günde 50-80g üzerinde alkol alımı CDT'yi artırır. Yarılanma ömrü 15 gündür, serum veya GIS' da bak1labilir.

EtG'nin vücut sıv1 ve dokularında uzun süre hatta saçta bir aya kadar tespiti mümkündür. Bağımlılıktan çok alkol alınımının bir göstergesidir. İdrar EtG değerlerinin örnekler 5 hafta boyunca 4 derecede saklandığında stabil kaldığı, yüksek ısıda ise değiştiği gözlenmiş [26]. Örnek alındıktan sonra içinde etanol ve Escherichia coli bulunan idrarda EtG'nin üreyebildiği rapor edilmiştir [27]. EtG, $\beta$-glukuronidaz aktivitesi gösteren bakterilerce 3-4 gün içinde tamamen parçalanırken, EtS 11 gün boyunca parçalanmadan kalabilmiştir [28].

Çürümüş cesetlerde ölümden birkaç saat önceki alkol alınımı ekarte edilmek isteniyorsa EtS parçalanma süresi gözönünde bulundurulmalıdır [29].

\section{KALP FONKSIYYONU ILE İLGILI BELİRTEÇLER}

\section{ANP, BNP ve N-terminal propeptidler}

Myokard iskemisinin biyokimyasal belirteçleri (cTnI, cTnT, myosin, myoglobin, CK ve CK-MB)

Atrial natriuretik peptid (ANP) ve brain natriuretik peptide (BNP) sırasiyla atrial ve ventriküler myokarddan sentezlenen ve salgilanan, 28 ve 32 amino asit içeren, küçük peptidlerdir. ProANP ve proBNP olarak üretilirler, parçalanarak aktif ANP, BNP ve amino-terminal (NT-proANP ve NT-proBNP) parçalarına ayrılırlar. Dolaşımda ANP ve NT-proANP artış1 artmış önyükü (preload), BNP ve NTproBNP artışı ise artmış ardyükü (afterload) gösterir.

Ağır myokard hasarında perikard sıvısındaki ANP ve BNP seviyeleri ile TroponinT (TnT) ara- sında negatif bir korelasyon vardır. Boğulmalarda (drowning) anlamlı ölçüde ANP, orta derecede BNP artışı görülür. BNP düzeyi ventriküler dilatasyonun derecesi ve kalp ve akciğerin ağırlıkları ile doğru orantılıdır. En yüksek NT-proBNP seviyelerine kronik kardiak iskemi ile ilișkili akut koroner tromboembolizm vakalarında rastlanılmış [30].

Akut myokard iskemisinde perikard sıvisı veya kalp kanında cTnI ve cTnT değerlerinin myokard hasarının derecesine bağlı olarak artış gösterdiği, CK-MB'nin ise uyumlu değerler göstermediği gözlenmiş $[31,33]$.

\section{SEPSIS, ENFLAMASYON VE ENFEKSIYYON}

\section{Serum procalcitonin (PCT), Akut faz proteinleri ve sitokinler, Neopterin}

Sepsisde PCT'in kesin orjini ve patofizyolojik rolu net olmamakla birlikte PCT'nin ağır sistemik bakteri, parazit ve mantar enfeksiyonlarında yüksek değerler gösterdiği bilinmektedir. Yarılanma ömrü uzundur (24-36 saattir). PCT sepsisde daha duyarl ve kan-GİS bariyerini daha iyi geçen bir belirteçtir.

Hipertermiye bağl1 ölümlerde patolojik ve toksikolojik delillerin bulunamadığ 1 durumlarda serum üre azotu, kreatinin ve CRP seviyelerinin birlikte değerlendirilmesi faydalıdır [11,13,34]. Sepsise bağlı ölümlerde sIL-2R ve LBP (lipopolisaccharide binding protein) artışı görülür [35]. IL-6 ve IL-8 travmatik nontravmatik ölümlerin ayırıcı tanısında yararlıdır, travma teşhisini kolaylaştırır [36-39].

Neopterin, monosit/makrofajlarda interferonların (Th1-type cytokine IFN- $\gamma$ ) indüklemesi ile üretilir. Viral, bakteriyal, protozoik, parazitik veya mantar enfeksiyonlarının görüldüğü sistemik enflamatuar cevap sendromunda (SIRS), romatoid artrit, insüline bağlı diabetes mellitus, sistemik lupus eritamatozis, multipl sklerozis, çöliak hastalığ1 ve romatizmal atește neopterin artışı görülebilir. Malign hastalıklarda tümörün başlaması, metastazı, gelişimi ve mortalitesi neopterin seviyeleri ile ilişkilidir. Transplantasyonlarda doku reddi ve/veya infeksiyöz komplikasyoların önemli bir göstergesi de olabilir. SIRS gelișmiș, travmaya bağlı geç ölüm vakalarında neopterin seviyeleri $500 \mathrm{ng} / \mathrm{mL}$ üzerindedir $[40,41]$. 


\section{ANAFLAKSİ}

\section{Triptaz ve şimaz}

Mast hücrelerinin granüllerinde heparin ve histaminin yanında triptaz ve şimaz gibi birçok proteaz bulunur. Anaflaksi (IgE bağımlı reaksiyonlar) ve anaflaktoid reaksiyon (IgE bağımsız ama benzer klinik reaksiyon) sonucu hücre dışına salınırlar. Normal kişilerin dolaşımında bulunan major triptaz formu $\alpha$-triptazdır, depolanmaz. $\beta$ II-triptaz mast hücre granüllerinde depolanır ve salınır. Ani bebek ölüm sendromu, eroin enjeksiyonuna bağlı ani ölüm, aterosklerotik kardiovasküler hastalık ve travmatik ölümlerde triptaz yüksektir $[42,43]$. Postmortem femoral ven kan serumunda $45 \mu \mathrm{g} / \mathrm{L}$ triptaz değeri referans değer olarak kabul edilir [44]. Triptaz ile şimaz arasında pozitif korelasyon vardır [45].

Histamin ölümden hemen sonra hızla salınır ve postmortem serumda tespit edilebilen iyi bir belirteçtir.

\section{HORMONLAR}

Adrenokortikotropik hormon (ACTH): BOS'da görülen düşük ACTH seviyeleri; uzun süre soğuğa maruz kalmaya bağlı azalmış hipofiz fonksiyonunun belirtisidir $[46,47]$.

Tiroid stimulan hormon (TSH), tiroglobulin (Tg), ve tiroid hormonları (TH): Postmortem kandaki T3 ve T4 değerleri antemortem referans değerlerle uyumludur. Soğukta düşük TSH değerleri gözlenir [48-50].

Katekolaminler: Adrenalin ve noradrenalinin (NA) GİS'daki değerleri kardiopulmoner resüsitasyon uygulananlarda anlamlı farklılık gösterdiği, kısa ve uzun agoniyi açıkca ayırt ettirici olduğu rapor edilmiştir. Hipotermide serum ve BOS katekolamin değerleri düşüktür. BOS NA değerleri ile adrenal medulla NA-immünpozitifliği arasında pozitif korelasyon vardır. Ölümcül derecede soğuğa maruziyetin sistemik ve ilerleyici sempatikoadrenomeduller sistemde bozukluğa neden olduğu rapor edilmiştir [51].

Kortizol: Postmortem idrar ve serumda kortizol değerlerinde 18 saat sonra hafif bir düşüş görülmüş. Canlı örneklerden çok da farklı değerlere rastlanılmamış [52].

Koryonik gonadotropin (HCG): Postmortemde gebe olanlarda pozitif, olmayanlarda negatif değerler elde edilmiş [53].
Eritropoietin (EPO): EPO, anemi veya hipoksiden 2 saat sonra yükselmeye başlar. Yarılanma ömrü 5-9 saattir. Postmortem EPO masif ve akut kanamalı yaralanmalara bağlı gelişen ölümlerde yaralanmadan sonraki yaşam süresini (ilk 6 saat içindeki) tahmin etmede kullanılabilecek bir belirteç olabilir [52].

\section{DİĞER BELİRTEÇLER}

Kromogranin A (Chromogranin A, CgA): Hipotermide serumda düşük, BOS'da yüksek, terminal dönemde ise düşük BOS değerleri ile uyumlu olarak düşük hipotalamus nöronal $\mathrm{CgA}$ immunpozitifliği görülür [54].

S100B: Klinikte, beyin hasarında (yaralanma, hipoksi/iskemi) prognozu tahmin etmede kullan1lan bir belirteçtir. Kafa yaralanmalarına bağlı beyin hasar1/hipoksi/iskemide serum ve BOS'da yükselir $[55,56]$.

Serotonin (5-HT): BOS ve perikardial sivida 5-HT değerleri sedatif-hipnotk ilaç zehirlenmesi ve hipertermide yüksek, hipotermide düşük bulunur [57,58].

Miyoglobin: Sıcak şoku, ağır yanıklar ve ağır kas hasar1, kas hiperaktivitesi veya ölümden hemen önce gelişen hipoksi ile ilişkili konvülsiv bozukluklarda idrarda artmış myoglobin değerlerine rastlanır [59-61].

\section{SONUÇ}

Biyokimyasal testlerle ilgili postmortem araştırmaların yetersizliği yanında test analitlerinin ölüm sonrası geçen zamana, test materyallerinin elde edilme yöntemine/yerine, ölen kişinin fizyopatolojik durumuna, kullanılan analitik yöntemlere, normal değerin ne olduğuna bağlı olarak değişkenlik göstermesi bu testlerin rutin kullanımını kısıtlamaktadır.

Postmortem biyokimyasal testler; postmortem teşhiste olayın hikayesi, radyolojik inceleme, makroskopik bulgular, histoloji ve toksikolojik araştırmalar olmadan tek başına yeterli olmayabilir. Ancak ölüm sebebini araştırma, ölüm anını belirleme ve ölümle ilişkili çevresel ve metabolik, genetik durumları aydınlatma konularında biyokimyasal incelemeler tartışmasız çok önemli bir yer tutmaktadır (biyokimyasal belirteçlerle ilgili özet bilgiler Tablo1'de verilmiştir). 
Tablo 1. Postmortem biyokimyasal belirteçler (özet)

\begin{tabular}{|c|c|c|c|c|c|}
\hline Belirteç & Örnek tipi & $\begin{array}{l}\text { Postmortem } \\
\text { süre }\end{array}$ & Yöntem & Değer & İlgili durum \\
\hline Glukoz & $\begin{array}{l}\text { Gis } \\
\text { BOS }\end{array}$ & 3-72 saat & Glukoz Peroksidaz & $\begin{array}{l}\geq 20 \mathrm{mmol} / \mathrm{L} \text { veya } \\
\geq 13 \mathrm{mmol} / \mathrm{L} \text { (GiS) }\end{array}$ & $\begin{array}{l}\text { Antemortem hipergli- } \\
\text { semi }\end{array}$ \\
\hline \multirow[t]{3}{*}{$\begin{array}{l}\text { Glikolize hemog- } \\
\text { lobin }\end{array}$} & Tam kan & $0-72$ saat & $\begin{array}{l}\text { HPLC } \\
\text { Latex }\end{array}$ & $\begin{array}{l}\% 3,5-6,2 \\
\text { (referans değer) }\end{array}$ & DM \\
\hline & & & Enzimatik & $\begin{array}{l}3 \mathrm{HB}>1000 \mu \mathrm{mol} / \mathrm{L} \text { (serum- } \\
\mathrm{da} \text { ) }\end{array}$ & Ketoasidoz \\
\hline & & & HS-GC & $>531 \mu \mathrm{mol} / \mathrm{L}$ (kan) & \\
\hline \multirow[t]{3}{*}{ Keton cisimleri } & $\begin{array}{l}\text { GiS, idrar se- } \\
\text { rum, kan }\end{array}$ & $0-96$ saat & & $\begin{array}{l}10000 \mu \mathrm{mol} / \mathrm{L} \text { (femoral kan) } \\
\text { ve } 5000 \mu \mathrm{mol} / \mathrm{L} \text { (GiS) }\end{array}$ & Alkolik ketoasidoz \\
\hline & & & & $\begin{array}{l}3 \mathrm{HB}>2400 \mu \mathrm{mol} / \mathrm{L} \text { (kan, id- } \\
\text { rar) }\end{array}$ & Patolojik \\
\hline & & & GC-FID & Aseton>2400 $\mu \mathrm{mol} / \mathrm{L}$ (kan) & Fatal ketoasidoz \\
\hline İnsülin & $\begin{array}{l}\text { Periferik kan se- } \\
\text { rumu }\end{array}$ & $\begin{array}{l}\text { En kısa sürede } \\
\text { çalışılmalı ve } \\
\text { dondurulmalı }\end{array}$ & & $\begin{array}{l}800-3200 \quad \mu \mathrm{lU} / \mathrm{ml}(556- \\
22,224 \mathrm{pmol} / \mathrm{l}) \text { veya } 100 \\
\mu \mathrm{Ul} / \mathrm{ml}\end{array}$ & Letal hipoglisemi \\
\hline Peptid C & $\begin{array}{l}\text { Periferik kan se- } \\
\text { rumu }\end{array}$ & $\begin{array}{l}\text { En kısa sürede } \\
\text { çalışılmalı ve } \\
\text { dondurulmalı }\end{array}$ & & $\begin{array}{l}\text { I/C }>1 \text { ise eksojen insulin , I/ } \\
C<1 \text { ise insulinoma veya sul- } \\
\text { fonilure aşırı dozu }\end{array}$ & $\begin{array}{l}\text { Eksojen insülin alımı- } \\
\text { nının ayırıcı tanısı }\end{array}$ \\
\hline Laktat & Gis, BOS & $0-72$ saat & Enzimatik & $23,4 \mathrm{mmol} / \mathrm{L}$ & DKA \\
\hline $\begin{array}{l}\text { Üre, } \\
\text { Ürik asit, krea- } \\
\text { tinin }\end{array}$ & Serum & $0-72$ saat & Enzimatik & $\begin{array}{l}\text { Klinik referans değerler } \\
\text { Ürik asidin sağ kalb kanında } \\
\text { artışı } \\
\text { kreatinin }>2 \mathrm{mg} / \mathrm{dL}\end{array}$ & $\begin{array}{l}\text { mekanik asfiksi ve bo- } \\
\text { ğulma } \\
\text { ölümcül hipertermi }\end{array}$ \\
\hline $\mathrm{Na}, \mathrm{Cl}$ & $\begin{array}{l}\text { Serum, Gis, } \\
\text { BOS }\end{array}$ & & & $\begin{array}{l}\text { Klinik referans değerler } \\
\mathrm{Na} \leq 120 \mathrm{mmol} / \mathrm{L}\end{array}$ & Hiponatremi \\
\hline $\mathrm{Ca}, \mathrm{Mg}$ & $\begin{array}{l}\text { Serum, perikard } \\
\text { sIVISI (PF) }\end{array}$ & $5-48$ saat & & $\begin{array}{l}\text { Klinik referans değerler (Ca } \\
\text { 8.7-10.1 mg/dl, } \\
\text { Mg 1.8-2.6 mg/dl) }\end{array}$ & $\begin{array}{l}\text { Tuzlu suda boğulma, } \\
\text { hipotermi }\end{array}$ \\
\hline Stronsiyum & $\begin{array}{l}\text { Sol/sağ ventri- } \\
\text { kül kanı, } \\
\text { Kalb ve femoral } \\
\text { kan }\end{array}$ & $\begin{array}{l}0-48 \text { saat } \\
30 \text { saat }\end{array}$ & AAS & $\begin{array}{l}\text { Sol ve Sağ kalp } \mathrm{Sr} \text { farkı } \\
75 \mu \mathrm{g} / \mathrm{L} \text {, } \\
\text { Sol ventrikül kanında } \\
172 \mu \mathrm{g} / \mathrm{L}\end{array}$ & Tuzlu suda boğulma \\
\hline $\begin{array}{l}\text { Total kolesterol } \\
\text { (TK), bilirubin, } \\
\text { protein }\end{array}$ & $\begin{array}{l}\text { Sağ kalb kanı } \\
\text { (TK), } \\
\text { Femoral kan }\end{array}$ & $0-72$ saat & $\begin{array}{l}\text { EO } \\
\text { Biüre }\end{array}$ & Klinik referans değerler & $\begin{array}{l}\text { Hiperkolesterolemi, } \\
\text { hepatit }\end{array}$ \\
\hline CDT & Femoral ve kalb & 6-96 saat & & $\begin{array}{l}\text { CDT }>17 \text { U/l erkek } \\
\text { ve }>25 \text { U/L kadın }\end{array}$ & \\
\hline ודם & Gis & (1-6 gün) & RIA & 4.7-24.5 U/I & Alkol kullanımı \\
\hline EtG & $\begin{array}{l}\text { İdrar, kan, ka- } \\
\text { raciğer, iskelet } \\
\text { kası, kaburga } \\
\text { kemik iliği }\end{array}$ & $\begin{array}{l}\text { 1-4 gün } \\
\text { (değişken) }\end{array}$ & $\begin{array}{l}\text { LC-MS/MS } \\
\text { LC-MS }\end{array}$ & & $\begin{array}{l}\text { İdrarda } 40 \text { de stabildir } \\
\text { Antemortem etanol } \\
\text { alımı }\end{array}$ \\
\hline EtS & İdrar, kan, Gis & $\begin{array}{l}\text { 1-7 gün } \\
\text { (değişken) }\end{array}$ & LC-MS/MS & & $\begin{array}{l}\text { Antemortem etanol } \\
\text { alımı }\end{array}$ \\
\hline
\end{tabular}


Tablo 1. Postmortem biyokimyasal belirteçler (özet) devamı

\begin{tabular}{|c|c|c|c|c|c|}
\hline Belirteç & Örnek tipi & $\begin{array}{l}\text { Postmortem } \\
\text { süre }\end{array}$ & Yöntem & Değer & İlgili durum \\
\hline $\begin{array}{l}\text { ANP, } \\
\text { NT-proANP, } \\
\text { NT-proBNP }\end{array}$ & $\begin{array}{l}\text { Femoral kan ve } \\
\text { serumu, } \\
\text { Gis, PF }\end{array}$ & & $\begin{array}{l}\text { Kemilüminesan immüno- } \\
\text { assey (IA) }\end{array}$ & Klinik referans değerler & $\begin{array}{l}\text { Kalp fonsiyon boz. } \\
\text { Ml }\end{array}$ \\
\hline $\begin{array}{l}\text { cTnT, cTnl, CK- } \\
\text { MB }\end{array}$ & Serum ve PF & 48 saat & $\begin{array}{l}\text { Elektrokemilüminesan IA } \\
\text { ve diğerleri }\end{array}$ & $\begin{array}{l}\text { Klinik referans değerler } \\
\text { cTnT'nin otopsi referans de- } \\
\text { ğeri daha yüksek }\end{array}$ & $\begin{array}{l}\text { Kalp krizi, myokard } \\
\text { hasarı }\end{array}$ \\
\hline Prokalsitonin & $\begin{array}{l}\text { Serum, femoral } \\
\text { kan, Gis, BOS, }\end{array}$ & 96 saat & $\begin{array}{l}\text { İmmünolüminometrik ve } \\
\text { semikantitatif }\end{array}$ & $\begin{array}{l}\text { Klinik referans değerler } \\
\text { (Tespit limilti } 0,25-0,3 \mathrm{ng} / \mathrm{mL} \text { ) }\end{array}$ & $\begin{array}{l}\text { Sistemik bakteri, para- } \\
\text { zit ve mantar enfeksi- } \\
\text { yonları }\end{array}$ \\
\hline CRP & $\begin{array}{l}\text { Periferik kan, } \\
\text { serum }\end{array}$ & 24-264 saat & İmmünotürbidimetrik & $\begin{array}{l}\text { Klinik referans değer }(10 \mathrm{~g} / \\
\mathrm{ml})\end{array}$ & Hipertermi \\
\hline $\begin{array}{l}\text { IL6 } \\
\text { IL8 }\end{array}$ & $\begin{array}{l}\text { Kalb kanı seru- } \\
\text { mu }\end{array}$ & 2 gün & ELISA & Klinik referans değer & $\begin{array}{l}\text { Travmatik ölümlerin } \\
\text { ayırıcı tanısı }\end{array}$ \\
\hline slL-2R ve LBP & $\begin{array}{l}\text { Kalb kanı seru- } \\
\text { mu }\end{array}$ & 48 saat & Kemilüminesan IA & Klinik referans değer & Sepsis \\
\hline Neopterin & İdrar, serum & 3saat-3 gün & HPLC & $\begin{array}{l}\text { Klinik değerlerden genellikle } \\
\text { yüksek }\end{array}$ & $\begin{array}{l}\text { İnfeksiyonlar, kanser, } \\
\text { SIRS, enflamasyonlar }\end{array}$ \\
\hline Triptaz, şimaz & $\begin{array}{l}\text { Femoral kan se- } \\
\text { rumu }\end{array}$ & $\begin{array}{l}3-5 \text { gün, } \\
4-110 \text { saat }\end{array}$ & $\begin{array}{l}\text { Floroenzim IA ve immü- } \\
\text { nofloroenzim assey }\end{array}$ & Referans değer $45 \mu \mathrm{g} / \mathrm{L}$ & Anaflaksi, \\
\hline ACTH & $\begin{array}{l}\text { Kalb kan seru- } \\
\text { mu, BOS }\end{array}$ & $4-85$ saat & $\begin{array}{l}\text { İmmünoradiometrik as- } \\
\text { sey }\end{array}$ & Klinik referans değer & Hipotermi \\
\hline TSH & $\begin{array}{l}\text { Kalb kan seru- } \\
\text { mu, BOS }\end{array}$ & 24 saat & Elektrokemilüminesan IA & Klinik referans değer & Hipotermi \\
\hline $\begin{array}{l}\text { Katekolaminler, } \\
\text { CgA }\end{array}$ & $\begin{array}{l}\text { Kalb kan seru- } \\
\text { mu, BOS }\end{array}$ & 3 gün & $\begin{array}{l}\text { ELISA } \\
\text { HPLC }\end{array}$ & $\begin{array}{l}\text { Klinik değerlerden daha yük- } \\
\text { sek }\end{array}$ & Agoni süresi, hipotermi \\
\hline Kortizol & $\begin{array}{l}\text { Femoral ve sağ } \\
\text { kalb kanı }\end{array}$ & 9-29 saat & Floresan metod & Klinik referans değer & \\
\hline EPO & Serum & 48 saat & RIA & $\begin{array}{l}\text { Klinik referans değer }(<36 \\
\mathrm{mU} / \mathrm{ml})\end{array}$ & $\begin{array}{l}\text { Masif ve akut kanamalı } \\
\text { yaralanmalarda ilk } 6 \\
\text { saat }\end{array}$ \\
\hline S100B & Serum, BOS & $48-72$ saat & ELISA & $\begin{array}{l}\text { Klinik değerlerden daha } \\
\text { yüksek, BOS'daki değeri se- } \\
\text { rumdan daha yüksek }\end{array}$ & Travmatik beyin hasarı \\
\hline Serotonin & BOS, PF & 48 saat & HPLC & $\begin{array}{l}\text { Klinik değerlerden daha yük- } \\
\text { sek, serum ve PF değerleri } \\
\text { eşit }\end{array}$ & $\begin{array}{l}\text { Sedatif-hipnotik ilaç } \\
\text { zehirlenmesi ve hiper- } \\
\text { termi }\end{array}$ \\
\hline Miyoglobin & $\begin{array}{l}\text { İdrar, kalb kan } \\
\text { serumu }\end{array}$ & 5saat-22 gün & RIA & $\begin{array}{l}\text { Serum ve idrar değerleri } \\
\text { uyumsuz }\end{array}$ & Ağır kas hasarı \\
\hline
\end{tabular}

AAS: Atomik Absorpsiyon Spektrometri, EO: Enzimatik oksidasyon, GC-FID: Gaz kromatografisi-alevli iyon dedektörü, GS-MS: Gaz kromatografisi-Kütle spektrometrisi, HPLC: Yüksek basınçlı sıvı kromatografisi, HS-GC: Headspace-gaz kromatografi, LC-MS: Sıvı kromatografisi-Kütle spektrometrisi, RIA: Radioimmünoassey 
Klinik uygulamada henüz yaygın olarak rutin incelemeler arasında yer alamayan, ancak birçok vakada başvurulması ve tam otopsi içinde değerlendirilmesi önemli olan biyokimyasal testlerin özellik arz eden durumlarda (diabetes mellitus, diabetik ve alkolik ketoasidoz, elektrolit bozuklukları, insülin enjeksiyonu, hipo/hipertermi, anaflaksi, sepsis, metabolik ve hormonal bozukluklar gibi) kullanılması ve rutin postmortem analizler içine alınması uygun olacaktır.

\section{KAYNAKLAR}

1. Coe JI. Postmortem chemistry update. Emphasis on forensic application. Am J Forensic Med Pathol 1993;14:91-117.

2. Traub F. [method for the detection of lethal glucose metabolism disorders in the corpse (diabetes mellitus and hypoglycemia)]. Zentralblatt fur allgemeine Pathologie und pathologische Anatomie 1969;112:390-399.

3. Karlovsek MZ. Diagnostic values of combined glucose and lactate values in cerebrospinal fluid and vitreous humour-our experiences. Forensic Sci Int 2004;146 Suppl:S19-23.

4. Zilg B, Alkass K, Berg S, Druid H. Postmortem identification of hyperglycemia. Forensic Sci Int 2009;185:89-95.

5. Palmiere C, Mangin P. Postmortem chemistry update part i. Int J Legal Med 2012;126:187-198.

6. Davis PL, Dal Cortivo LA, Maturo J. Endogenous isopropanol: Forensic and biochemical implications. J Analytic Toxicol 1984;8:209-212.

7. Thomsen JL, Felby S, Theilade P, Nielsen E. Alcoholic ketoacidosis as a cause of death in forensic cases. Forensic Sci Int 1995;75:163-171.

8. Pounder DJ, Stevenson RJ, Taylor KK. Alcoholic ketoacidosis at autopsy. J Forensic Sci 1998;43:812-816.

9. Patel F. Fatal self-induced hyperinsulinaemia: A delayed post-mortem analytical detection. Med Science Law 1992;32:151-159.

10. Kernbach-Wighton G, Puschel K. On the phenomenology of lethal applications of insulin. Forensic Sci Int 1998;93:6173.

11. Maeda H, Zhu BL, Bessho Y, et al. Postmortem serum nitrogen compounds and c-reactive protein levels with special regard to investigation of fatal hyperthermia. Forensic Sci Med Pathol 2008;4:175-180.

12. Uemura K, Shintani-Ishida K, Saka K, et al. Biochemical blood markers and sampling sites in forensic autopsy. J Forensic Legal Med 2008;15:312-317.

13. Whitehead FJ, Couper RT, Moore L, et al. Dehydration deaths in infants and young children. Am J Forensic Med Pathol 1996;17:73-78.

14. Ross MP, Spiller HA. Fatal ingestion of sodium hypochlorite bleach with associated hypernatremia and hyperchloremic metabolic acidosis. Vet Human Toxicol 1999;41:82-86.
15. Byard RW. Incapacitation or death of a socially isolated parent or carer could result in the death of dependent children. J Paediatr Child Health 2002;38:417-418.

16. Chen X, Huang G. Autopsy case report of a rare acute iatrogenic water intoxication with a review of the literature. Forensic Sci Int 1995;76:27-34.

17. Zhu BL, Ishikawa T, Quan L, et al. Evaluation of postmortem serum calcium and magnesium levels in relation to the causes of death in forensic autopsy. Forensic Sci Int 2005; 155:18-23.

18. Li DR, Quan L, Zhu BL, et al. Evaluation of postmortem calcium and magnesium levels in the pericardial fluid with regard to the cause of death in medicolegal autopsy. Leg Med (Tokyo) 2009;11 Suppl 1:S276-278.

19. Azparren JE, Vallejo G, Reyes E, et al. Study of the diagnostic value of strontium, chloride, haemoglobin and diatoms in immersion cases. Forensic Sci Int 1998;91:123-132.

20. Azparren J, de la Rosa I, Sancho M. Biventricular measurement of blood strontium in real cases of drowning. Forensic Sci Int 1994;69:139-148.

21. Azparren JE, Ortega A, Bueno H, Andreu M. Blood strontium concentration related to the length of the agonal period in seawater drowning cases. Forensic Sci Int 2000;108:5160 .

22. Azparren JE, Fernandez-Rodriguez A, Vallejo G. Diagnosing death by drowning in fresh water using blood strontium as an indicator. Forensic Sci Int 2003;137:55-59.

23. Azparren JE, Perucha E, Martinez P, et al. Factors affecting strontium absorption in drowning. Forensic Sci Int 2007; 168:138-142.

24. Azparren JE, Cubero C, Perucha E, et al. Comparison between lung weight and blood strontium in bodies found in seawater. Forensic Sci Int 2007;168:128-132.

25. Perez-Carceles MD, del Pozo S, Sibon A, et al. Serum biochemical markers in drowning: Diagnostic efficacy of strontium and other trace elements. Forensic Sci Int 2012;214:159-166

26. Schloegl H, Dresen S, Spaczynski K, et al. Stability of ethyl glucuronide in urine, post-mortem tissue and blood samples. Int J Legal Med 2006;120:83-88.

27. Helander A, Olsson I, Dahl H. Postcollection synthesis of ethyl glucuronide by bacteria in urine may cause false identification of alcohol consumption. Clin Chem 2007;53:1855-1857.

28. Baranowski S, Serr A, Thierauf A, et al. In vitro study of bacterial degradation of ethyl glucuronide and ethyl sulphate. J Forensic Legal Med 2008;122:389-393.

29. Halter CC, Laengin A, Al-Ahmad A, et al. Assessment of the stability of the ethanol metabolite ethyl sulfate in standardized degradation tests. Forensic Sci Int 2009;186:5255 .

30. Zhu BL, Ishikawa T, Michiue T, et al. Postmortem pericardial natriuretic peptides as markers of cardiac function in medico-legal autopsies. Int J Legal Med 2007;121:28-35.

31. Zhu BL, Ishikawa T, Michiue T, et al. Postmortem cardiac troponin $\mathrm{i}$ and creatine kinase mb levels in the blood and 
pericardial fluid as markers of myocardial damage in medicolegal autopsy. Leg Med (Tokyo) 2007;9:241-250.

32. Zhu BL, Ishikawa $\mathrm{T}$, Michiue $\mathrm{T}$, et al. Postmortem cardiac troponin $t$ levels in the blood and pericardial fluid. Part 2: Analysis for application in the diagnosis of sudden cardiac death with regard to pathology. Leg Med (Tokyo) 2006;8:94-101.

33. Zhu BL, Ishikawa T, Michiue T, et al. Postmortem cardiac troponin $t$ levels in the blood and pericardial fluid. Part 1. Analysis with special regard to traumatic causes of death. Leg Med (Tokyo) 2006;8:86-93.

34. Ishikawa T, Hamel M, Zhu BL, et al. Comparative evaluation of postmortem serum concentrations of neopterin and c-reactive protein. Forensic Sci Int 2008;179:135-143.

35. Reichelt U, Jung R, Nierhaus A, Tsokos M. Serial monitoring of interleukin-1beta, soluble interleukin-2 receptor and lipopolysaccharide binding protein levels after death a comparative evaluation of potential postmortem markers of sepsis. Int J Legal Med 2005;119:80-87.

36. Mimasaka S, Hashiyada M, Nata M, Funayama M. Correlation between serum il-6 levels and death: Usefulness in diagnosis of "traumatic shock"? Tohoku J Exp Med 2001;193:319-324.

37. Mimasaka S. Postmortem cytokine levels and the cause of death. Tohoku J Exp 2002;197:145-150.

38. Mimasaka S, Ohtsu Y, Tsunenari S, Funayama M. Postmortem cytokine levels and severity of traumatic injuries. J Forensic Legal Med 2006;120:265-270.

39. Mimasaka S, Funayama M, Hashiyada M, et al. Significance of levels of il-6 and il-8 after trauma: A study of 11 cytokines post-mortem using multiplex immunoassay. Injury 2007;38:1047-1051.

40. Schrag B, Roux-Lombard P, Schneiter D, et al. Evaluation of c-reactive protein, procalcitonin, tumor necrosis factor alpha, interleukin-6, and interleukin-8 as diagnostic parameters in sepsis-related fatalities. J Forensic Legal Med 2012; 126:505-512.

41. Ambach E, Tributsch W, Fuchs D, et al. Postmortem evaluation of serum and urine neopterin concentrations. J Forensic Sci 1991;36:1089-1093.

42. Edston E, van Hage-Hamsten M. Mast cell tryptase and hemolysis after trauma. Forensic Sci Int 2003;131:8-13.

43. Buckley MG, Variend S, Walls AF. Elevated serum concentrations of beta-tryptase, but not alpha-tryptase, in sudden infant death syndrome (sids). An investigation of anaphylactic mechanisms. Clin Exp allergy 2001;31:1696-1704.

44. Edston E, van Hage-Hamsten M, Johansson SG. Tryptase-at last a useful diagnostic marker for anaphylactic death. Allergy 1996;51:443-445.

45. Nishio H, Takai S, Miyazaki M, et al. Usefulness of serum mast cell-specific chymase levels for postmortem diagnosis of anaphylaxis. Int J Legal Med 2005;119:331-334.

46. Ishikawa T, Quan L, Li DR, et al. Postmortem biochemistry and immunohistochemistry of adrenocorticotropic hormone with special regard to fatal hypothermia. Forensic Sci Int 2008;179:147-151.
47. Ishikawa T, Miyaishi S, Tachibana T, et al. Fatal hypothermia related vacuolation of hormone-producing cells in the anterior pituitary. Leg Med (Tokyo) 2004;6:157-163.

48. Edston E, Druid H, Holmgren P, Ostrom M. Postmortem measurements of thyroid hormones in blood and vitreous humor combined with histology. Am J Forensic Med Pathol 2001;22:78-83.

49. Dressler J, Mueller E. High thyroglobulin (tg) concentrations in fatal traumatic brain injuries. The American journal of forensic medicine and pathology 2006;27:280-282.

50. Ishikawa T, Michiue T, Zhao D, et al. Evaluation of postmortem serum and cerebrospinal fluid levels of thyroidstimulating hormone with special regard to fatal hypothermia. Leg Med (Tokyo) 2009;11 Suppl 1:S228-230.

51. Wilke N, Janssen H, Fahrenhorst C, et al. Postmortem determination of concentrations of stress hormones in various body fluids--is there a dependency between adrenaline/ noradrenaline quotient, cause of death and agony time? Int J Legal Med 2007;121:385-394.

52. Quan L, Zhu BL, Ishikawa T, et al. Postmortem serum erythropoietin levels in establishing the cause of death and survival time at medicolegal autopsy. Int J Legal Med 2008;122:481-487.

53. Fanton L, Bevalot F, Cartiser N, et al. Postmortem measurement of human chorionic gonadotropin in vitreous humor and bile. J Forensic Sci 2010;55:792-794.

54. Yoshida C, Ishikawa T, Michiue T, et al. Postmortem biochemistry and immunohistochemistry of chromogranin a as a stress marker with special regard to fatal hypothermia and hyperthermia. Int J Legal Med 2011;125:11-20.

55. Li DR, Zhu BL, Ishikawa T, et al. Immunohistochemical distribution of s-100 protein in the cerebral cortex with regard to the cause of death in forensic autopsy. Leg Med (Tokyo) 2006;8:78-85.

56. Ondruschka B, Pohlers D, Sommer G, et al. S100b and nse as useful postmortem biochemical markers of traumatic brain injury in autopsy cases. J Neurotrauma 2013;30:18621871.

57. Quan L, Ishikawa T, Hara J, et al. Postmortem serotonin levels in cerebrospinal and pericardial fluids with regard to the cause of death in medicolegal autopsy. Leg Med (Tokyo) 2011;13:75-78.

58. Musshoff F, Menting T, Madea B. Postmortem serotonin (5ht) concentrations in the cerebrospinal fluid of medicolegal cases. Forensic Sci Int 2004;142:211-219.

59. Puschel K, Lockemann U, Bartel J. Postmortem investigation of serum myoglobin levels with special reference to electrical fatalities. Forensic Sci Int 1995;72:171-177.

60. Fieguth A, Schumann G, Troger HD, Kleemann WJ. The effect of lethal electrical shock on postmortem serum myoglobin concentrations. Forensic Sci Int 1999;105:75-82.

61. Zhu BL, Ishida K, Quan L, et al. Post-mortem urinary myoglobin levels with reference to the causes of death. Forensic Sci Int 2001;115:183-188. 